\title{
Constitutional Law: Ideas in the Public Forum
}

\author{
Robert B. McKay*
}

It is not for the state to control the influence of a public forum by censoring the ideas, the proponents, or the audience; if it could, that freedom which is the life of democratic assembly would be stilled. And the dulling effects of censorship on a community are more to be feared than the quickening influence of a live interchange of ideas. $\dagger$

R oger John Traynor is clearly a man in love with the law. In more 1 than 800 opinions as Associate Justice and now as Chief Justice of the Supreme Court of California, and in more than a score of extrajudicial statements on legal subjects he has demonstrated that his romance with the law is no dalliance of the moment but a lifelong passion. The affair is one in which the feeling is mutual. Chief Justice Traynor has been received into the select company of the Great Men of the Law. That society holds no elections; it presents no annual awards; and there may even be uncertainty as to the exact membership rolls, but none can doubt that Roger Traynor is a member in good standing.

Chief Justice Traynor has made his mark without apparent effort. He has given each case, the commonplace as well as the exotic, the trivial as well as the epochal, the same careful scrutiny in order to reach the fairest possible result consistent with contemporary legal standards. Indeed, Roger Traynor has displayed a seeming carelessness for his own reputation for judicial regularity. Where others tread the careful path that leads safely to mechanical application of established law, sometimes avoiding the reasoned opinion in favor of string citations of fitfully relevant precedent, Traynor has asked bold, hard questions about the law; and his inquiries have sometimes led him to venture new answers to old questions. He has challenged inappropriate stability as well as heedless change. ${ }^{1}$

Always clear and often eloquent in his opinions, Chief Justice Traynor can be blunt where plain words are demanded. In addition, he has written extensively, and well, in the law reviews, always testing frontier ideas against accepted notions, inviting discussion of the judicial process ${ }^{2}$

*B.S. 1940, University of Kansas, LL.B. 1947, Yale University. Associate Dean and Professor of Law, New York University.

$\dagger$ Danskin v. San Diego Unified School Dist., 28 Cal. 2d 536, 548, 171 P.2d 885, 893 (1946) (Traynor, J.).

1 See Traynor, Better Days in Court for a New Day's Problems, 17 VAND. L. Rev. 109 (1963).

2 See, e.g., Comment on The Courts and Lawmaking, in Legax Instrudurions Today 
and of substantive problems in the law..$^{3}$ Moreover, he has labored diligently in counseling otliers both by way of public address and in the classic teacher-student relationship of the seminar. ${ }^{4}$

In Chief Justice Traynor's first quarter of a century as a member of the Supreme Court of California, there is no corner of the law into which he has not had occasion to probe. No part of the law has proved less than interesting to him. It is my pleasant task to consider Chief Justice Traynor's contributions to one area of special interest to him, the alwaysenigmatic field of constitutional law, particularly in relation to the first amendment freedoms. But first there are preliminary questions: (1) What is there in the judicial philosophy of this state court justice that has made it possible for him to play such a significant role in the development of federal constitutional law? (2) What has been the extent of that impact? (3) What is Chief Justice Traynor's general constitutional philosophy into which his first amendment views must be fitted?

\section{I}

JUSTICE TRAYNOR AND THE PROBLEMS OF THE STATE COURT JUDGE

Some state judges-too many-have avoided reasoned answers to questions arising under the United States Constitution or federal statutes. The temptation is to rely on what pass for omens of precedential wisdom from the United States Supreme Court, however distinguishable, or however eroded by the passage of time and by change from the circumstances that made the original decision reasonable in its day. But

AND TOMorrow 48 (Paulsen ed. 1959); No Magic Words Could Do. It Justice, 49 CaLIF. L. REv. 615 (1961); A Time to Build Up, 35 CALIF. S.B.J. 219 (1960); Some Open Questions on the Work of State Appellate Courts, 24 U. Cमr. L. REv. 211 (1957); La Rude Vita, La Dolce Giustizia; Or Hard Cases Can Make Good Law, 29 U. CHI. L. REv. 223 (1962); Law and Social Change in a Democratic Society, 1956 U. IIL. L.F. 220; Fact Skepticism and the Judicial Process, 106 U. PA. L. Rev. 635 (1958); Badlands in an Appellate Judge's Realm of Reason, 7 UTAF L. Rev. 157 (1960); Better Days in Court for a New Day's Problems, 17 VAND. L. REv. 109 (1963).

${ }^{3}$ Mapp v. Ohio at Large in the Fifty States, 1962 Dure L.J. 319; Unjustifiable Reliance, 42 MnNN. L. REv. 11 (1957); Ground Lost and Found in Criminal Discovery, 39 N.Y.U.L. REv. 228 (1964); Ground Lost and Found in Criminal Discovery in England, 39 N.Y.U.L. REv. 749 (1964); Is This Conflict Really Necessary? 37 TExAs L. Rev. 657 (1959). In addition, there are a number of articles on state taxation, book reviews, and biographical tributes.

4 Before appointment to the bench Roger Traynor had been for several years a member of the law faculty of Boalt Hall, University of California, Berkeley, and ever since he has responded generously to invitations for formal lectures or for informal discussions. For example, each summer since 1958 he has served as a member of the "faculty" for the Appellate Judges Workshops held at New York Umiversity. During that saine period he has regularly made himself available for roundtable discussions with law teachers in attendance at the Special Summer Program for Law Teachers and at the Subject-Matter Workshops at which both "faculty" and "students" are law teachers. 
this is not the course that Roger Traynor has set for himself and other state court judges bold enough to follow where he would lead:

[A] state appellate court can also do much for the orderly development of law by articulating the issues and setting forth clearly the reasons for its decision. That responsibility is the greater when there appears to be no controlling case or even clear trend in the pertinent federal authorities that would afford a basis for predicting how the United States Supreme Court will decide in the event of an appeal or petition for certiorari ....5

Moreover, even when there is a pertinent Supreme Court decision, but one which appears to have lost its authority, "a state court must verify with painstaking care the signs that it is moribund. If it is, and only the official death notice remains to be pronounced, a state court may reason that it is wiser though substantially more difficult to administer appropriate last rites than to pretend a case is still alive that is about to be pronounced dead."

Chief Justice Traynor understands perfectly well why the ordinary judge rejects boldness and "marks time instead on the line of least resistance and lets bad enough alone." But that attitude will neither sustain the law nor nurture its growth. "The real danger to law is not that judges might take off onward and upward, but that all too many of them have long since stopped dead in the tracks of their predecessors ....."

For a state court judge-or any judge-to play the useful and creative role that Roger Traynor thinks proper, there is no substitute for testing the judicially preferred result against the exacting standard: "Will it write?" The "grievous sins of garrulousness and pretension" are not so much the danger as the failure to reach a proper result because no adequate attempt was made in the hard case to reason it out. Traynor put the problem this way in 1957: "I have not found a better test for the solution of a case than its articulation in writing, which is thinking at its hardest." As he observed another time, "There can be idle silence as well as idle talk."

In the area of federal constitutional law, as in all areas of the common law, the judicial opportunity for creativity is confined by the

5 Traynor, Badlands in an Appellate Judge's Realm of Reason, 7 UTAE L. REv. 157, 168 (1960).

6 Ibid.

TId. at 166. See also Traynor, No Magic Words Could Do It Justice, 49 CaLIF. L. REv. 615, 621 (1961).

8 Traynor, supra note 7 , at 621 .

9 Traynor, Some Open Questions on the Work of State Appellate Courts, 24 U. CHI. L. REv. 211, 218 (1957).

10 Traynor, supra note 7 , at 620 . 
limited range within which an appellate judge may review the facts of a case before him and by the less tangible, but nonetheless real, restrictions of the doctrine of precedent.

Many forces constrain review within extremely narrow limits .... The normal controversy is so involved in precedent as to preclude the most timid flight of fancy. The judge's most serious problem is which of competing lines of precedent to follow. Far from having the freedom of the skies where plane the test pilots of the legislature, he is himited to the hardly delirious choice of plodding along one well-dug ditch after another-reflecting as he meekly plods that what he has inherited is a mighty narrow piece of earth. ${ }^{11}$

In addition, where interpretation of the United States Constitution is involved, the creativity of the state court judge is further limited by the doctrine of federal supremacy, a matter itself ordained by article VI of the Constitution. State courts, thus advised that they are not their own masters, are likely to attempt too little lest they be charged with attempting too much. Roger Traynor has understood the proper balance differently. In constitutional litigation, as in common-law matters, he has recognized the obligation to be one of weighing and comparing precedent, of testing the continuing vitality of that found applicable, and of making reasoned judgment.

That this is a true balance is attested by the impact on federal constitutional law of decisions from the California Supreme Court, and particularly those of Chief Justice Traynor, whether majority, concurring, or dissenting opinions. If "the best test of truth is the power of the thought to get itself accepted in the competition of the market. ..." as Justice Holmes observed nearly fifty years ago, ${ }^{12}$ Chief Justice Traynor's opinions have satisfied that test.

\section{II}

IMPACT ON FEDERAT CONSTITUTIONAI LAW

Roger Traynor's contributions to the development of federal constitutional law have been substantial. Throughout he has demonstrated great sensitivity in seeking protection for the rights of individuals agaimst the wrongs that may be done them by an occasionally indifferent or forgetful society. Chief Justice Traynor's significant role in the stillunfolding catalogue of due process requirements in state criminal proceedings is comprehensively reviewed by Professor Monrad Paulsen. ${ }^{18}$

11 Ibid.

12 Abrams v. United States, 250 U.S. 616, 630 (1919) (dissenting opinion).

13 Paulsen, The Contributions of Roger J. Traynor-Criminal Law Administration: The Zero Hour Was Coming, infra this Symposiun. 
Suffice it here to say that Chief Justice Traynor has demonstrated how the important values of right to counsel, freedom from unreasonable search and seizure, the privilege against self-incrimination, and other aspects of criminal proceedings can be effectively guaranteed without disturbance to law and order.

In the increasingly vital area of judicial invalidation of discrimination on grounds of race or national origin, Chief Justice Traynor has several times previewed future doctrinal shifts. In his concurring opinion in People v. Oyama ${ }^{14}$ he raised doubts as to the continuing vitahty of rulings which he nevertheless considered binding until overruled by the Supreme Court. Petitioner had challenged the validity of state-imposed burdens on the ownership and transferability of land by persons ineligible for citizenship. Traynor argued that the precedents which permitted such discrimination had been drained of much of their force, and he pressed for their repudiation. ${ }^{15}$ The Supreme Court of the United States did indeed reverse the California judgment, as Justice Traynor had in effect recommended, but on the narrower ground that the statute had been applied in an unconstitutional way. ${ }^{16}$ The same year, in Takahashi v. Fish and Game Commission, ${ }^{17}$ also a California case, the Supreme Court went nearly the whole distance, invalidating a statute barring issuance of commercial fishing hicenses to persons "ineligible to citizenship." Without quite overruling the cases of which Justice Traynor had complained, the Court so isolated the earlier decisions that they have not been heard from since.

On the related issue of racial discrimination, the California Supreme Court, through Justice Traynor in 1948, ruled invalid the state antimiscegenation statute as violative of the equal protection of the laws, ${ }^{18}$ despite an 1883 Supreme Court ruling apparently to the contrary. ${ }^{19}$ Sixteen years later the Supreine Court more gingerly reached almost the same result, but without quite overruling the earher precedent. ${ }^{20}$

On one occasion Justice Traynor outstripped all his colleagues in his willinguess to overcome the force of racial discrimination. In Hughes $v$. Superior Court ${ }^{21}$ the majority of the California Supreme Court enjoined

1429 Cal. 2d 164, 173 P.2d 794 (1946).

15 The cases were Frick v. Webb, 263 U.S. 326 (1923); Webb v. O'Brien, 263 U.S. 313 (1923); Porterfield v. Webb, 263 U.S. 225 (1923); Terrace v. Thompson, 263 U.S. 197 (1923).

16 Oyama v. California, 332 U.S. 633 (1948).

17334 U.S. 410 (1948).

18 Perez v. Sharp, 32 Cal. 2d 711, 198 P.2d 17 (1948). See Armstrong, The Contributions of Roger J. Traynor-Family Law: Order out of Chaos, infra this Symposium.

10 Pace v. Alabama, 106 U.S. 583 (1883).

20 McLaughlin v. Florida, 379 U.S. 184 (1964).

2132 Cal. 2d 850, 198 P.2d 885 (1948). 
Negro petitioners from picketing a store to compel the hiring of Negro clerks in proportion to the volume of Negro business. Traynor, dissenting, contended that the picketing contained none of the nonspeech elements which might justify an injunction: "Those racial groups against whom discrimination is practiced may seek economic equality either by demanding that hiring be done without reference to race or color or by demanding a certain number of jobs for members of their group."22 On review by the Supreme Court of the United States no member of that Court went along with the Traynor dissent. ${ }^{23}$ But 1965 is not 1950 . One might guess that today additional sympathy might be found for the Traynor dissent, delivered long before the civil rights movement had gathered significant community support and before the new constitutional positions relating to racially discriminatory practices had been fully developed.

It should not go without notice that in the area of labor relations, although affected more by federal statute than by the federal Constitution, Justice Traynor has also written a number of influential decisions. Thus, in comrection with the troublesome question as to how much authority the state courts retain over labor practices allegedly within the regulatory jurisdiction of federal agencies, Chief Justice Traynor's views have ordinarily prevailed. When the United States Supreme Court determined that Cahifornia could not enjoin conduct within the jurisdiction of the National Labor Relations Board, even though the Board had not exercised its jurisdiction, and remanded the case to the California Supreme Court for further proceedings, that court held that the award of damages was neither precluded by the ruling of the United States Supreme Court nor forbidden by state law. ${ }^{24}$ Justice Traynor disagreed on both grounds and was vindicated on both. Believing that the majority misread the opimion of the United States Supreme Court, he suggested that the High Court had merely asked for advice on the state question to determine whether a ruling could be avoided on the federal question. The Supreme Court agreed, reversing the state court judgment and holding that the National Labor Relations Act precluded the state courts from awarding damages for economic injuries resulting from the peaceful picketing of their plant by labor unions which had not been selected as bargaining agents by a majority of the employees. ${ }^{25}$ Even apart from the federal pre-emption thus effected in that case, Justice Traynor dis-

22 Id. at 868,198 P.2d at $895-96$.

23 Hughes v. Superior Court, 339 U.S. 460 (1950).

24 Garmon v. San Diego Building Trades Council, 49 Cal. 2d 595, 320 P.2d 473 (1958).

25 San Diego Building Trades Council v. Garmon, 359 U.S. 236 (1959). 
agreed with his colleagues' interpretation of the state law; lie believed that established doctrine forbade the award of damages for peaceful picketing in the circumstances of the case. In a 1960 opinion written by Traynor the California Supreme Court agreed, overruling the interpretation of state law to which lie had taken exception in Garmon. ${ }^{26}$

\section{III}

\section{FIRST AMENDMENT FREEDOMS}

Pamphleteers are likely to say that freedom is indivisible; and so it is in the sense that those willing to demigrate one freedom are ordinarily willing to downgrade all freedoms. But for the working judge the question has different prismatic aspects. However cognizant he may be of the interrelationship of the various freedoms of mind and conscience, problems come to him in terms of individual cases requiring individual solutions. It must, therefore, sometimes be difficult for a judge to keep in mind the grand design of the tapestry while he is weaving, or perliaps only reweaving, a remote corner in which the whole plan is not disclosed. In twenty-five years, thougl, a judge to whom lias been revealed the majesty of the whole can weave his corners meaningfully and find at last that he has put together much of the final pattern.

Roger Traynor is suclı a judge in the first amendment area. While recognizing that freedom of speech, freedom of the press, freedom of association, freedom of religion, and separation of Cliurch and State are for some purposes distinct, requiring somewliat different formulation, still the whole is greater than the sum of the parts. For our purposes it is appropriate to examine the parts that make up that whole and then to review once more, from the perspective of hindsight, the whole philosophy.

Chief Justice Traynor's opinions in the first amendment area reveal a comprehensive and considered philosophy of that amendment. Where he lias suggested doctrine in advance of its securing the imprimatur of acceptance by the Supreme Court of the United States, his formulation of the problem and of recommended solutions has in every case been influential. Even in those instances in which his views have not been accepted, his are the ideas against which the ultimately prevailing doctrine

28 Petri Cleaners, Inc. v. Automotive Employees Local No. 88, 53 Cal. 2d 455, 349 P.2d 76, 2 Cal. Rptr. 470 (1960).

Other opinions in the labor relations area are tangential to the present discussion and too numerous for analysis here. But mention should be made at least of McCarroll v. Los Angeles County Carpenters, 49 Cal. 2d 45, 315 P.2d 322 (1957), cert. denied, 355 U.S. 932 (1958), which suggested a solution for some of the controverted jurisdictional issues in connection with state court injunctions against strikers in breach of "no strike" clauses. 
must be tested. An idea which can withstand the rigorous Traynor logic is an idea not to be lightly dismissed.

Central to the Traynor constitutional philosoplyy is his abiding faith that the Constitution of the United States is a charter of liberty and equality. His insistence on fairness in criminal proceedings and his outrage at state-supported racial discrimination have been commented on here and elsewhere in this Symposium.

But there is more. Roger Traynor believes in the Constitution because it speaks on behalf of freedom. "Freedom," he has said, "is more than a synonym for the right to speak and to know. It is also the antithesis of conformity ...."27 In the sometimes uneasy fight to uphold the principles of freedom, Chief Justice Traynor has commended "the stalwarts of freedom ... [who] have taken thouglit for those who nurse their bones in cozy corners of conformity or drill themselves into stupefication to achieve agility in crawling under barbed wire or racing to the moon. The freedom they speak of is large enough to accommodate the inquiry of those who would know more than the target or soup for the day. They lave known mountainous terrain where men may walk in solitude to new perspectives, where they rope themselves together only for an affair of survival and not as a matter of course. They give reassurance to the world that in this country the free lave yet to be outnumbered."28

The first question in reviewing a judicial philosophy of the first amendment is to determine the extent to which the seemingly imperative "thou shalt nots" of the amendment are read as absolutes or as strong preferences whicli may nonetheless be balanced away to some extent as compared with other governmental powers or constitutional limitations. Without reliearsing again that mucli-debated question, it is sufficient here to remind of the opposing views as articulated by their chief protagonists, Justices Hugo Black and Felix Frankfurter. One preliminary caution is no doubt appropriate. However great may liave been the difference between these two, it must be recalled that the debate is one of refinement. There is agreement that the commands of the first amendment are "fundamental" to "the concept of ordered hiberty" and so must apply with essentially the same force as limitations upon the national government and upon state governments. Long gone are the days when the "bad tendency" test could be used to sustain legislation restrictive of speech; ${ }^{29}$ when motion pictures were subject to official censorslip for

27 Traynor, Book Review, 46 CarIF. I. Rev. 301, 304 (1958).

28 Id. at 308.

29 Compare Gitlow v. New York, 268 U.S. 652 (1925) with Dennis v. United States, 341 U.S. 494 (1951) and Yates v. United States, 354 U.S. 298 (1957). 
the all-embracing reason that they were commercial ventures; ${ }^{30}$ when religious liberty received scant recognition; ${ }^{31}$ and when the separation of Church and State was largely theoretical and untested. ${ }^{\mathbf{2}}$

The issue that long divided Justices Black and Frankfurter was the narrower question of determining how strictly the prohibitions must be read to give sufficient force to the guarantees of the first amendment. Justice Black spoke in terms of "absolutes" and a hiteral reading of the prohibitions, ${ }^{33}$ while Justice Frankfurter always read the prohibitions as words of limitation addressed to the sound exercise of judicial discretion. From this Frankfurter view naturally developed the notion that the first amendment rights were to be balanced against the legislatively professed necessities of nation or state. ${ }^{34}$ When applied with a generous sprinkling of judicial self-restraint, this philosophy often produced judicial acquiescence in legislative limitations on freedom that did not seem, "in the circumstances," too extreme.

It will do hittle good to seek to line up Justice Traynor with one or another of these positions. If his opmions, no doubt sometimes written to hold a majority, seem occasionally to lean toward the pragmatics of balancing, his own writings, where he is responsible to no one save himself, suggest his faith in freedom as reviewed by the generously indulgent eyes of a judiciary, constrained to protect against legislative encroachment.

Justice Traynor has poked gentle fun at the notion that difficulties of constitutional exegesis could be somehow miraculously simplified by the search for "neutral principles,"

The composite ideal of the professors, if I abstract it aright, is a judge who, after marshalling an impressive array of relevant facts, can write an opinion that gives promise of more than a three-year lease on life by accurately anticipating the near future, wlio respects established folk patterns by not anticipating the too distant future,

80 Compare Mutual Film Corp. v. Industrial Comm'n, 236 U.S. 230 (1915). with Joseph Burstyn, Inc. v. Wilson, 343 U.S. 495 (1952).

81 Compare Jones v. Opelika, 316 U.S. 584 (1942), vacated, 319 U.S. 103 (1943) with Murdock v. Pennsylvania, 319 U.S. 105 (1943).

82 Everson v. Board of Educ., 330 U.S. 1 (1947) was the first case to state a reasoned philosophy of the meaning of the establishment clause of the first amendment.

33 See Black, The Bill of Rights and the Federal Government, in THE GREAT RIGHTS 43 (Cahn ed. 1963); Justice Black and First Amendment "Absolutes": A Public Interview, 37 N.Y.U.L. REv. 549 (1962).

34 See, e.g., Sweezy v. New Hampshire, 354 U.S. 234, 255, 261-67 (1957) (Frankfurter, J., concurring); .Dennis v. United States, 341 U.S. 494, 517, 521-28 (1951) (Frankfurter, J., concurring).

35 See Wechsler, Toward Neutral Principles of Constitutional Law, 73 HaRv. L. Rev. 1 (1959). 
and who walks a tightrope of logic to the satisfaction of a team of collective thinkers as well as to the plaudits of the philosophers. ${ }^{30}$

When the "quest for appropriate judicial standards centers around constitutional law cases, where judicial latitude is broadest . . ." ${ }^{37}$ there are no "magic words" whose incantation will conjure up solutions.

Every judge worthy of the title comes to his office with a set of values to some extent preset, but which, in the best tradition, should be capable of growth and development through the years of his judicial service. Chief Justice Traynor is no exception. He came to the bench in 1940, already known as a skilled law teacher and specialist in the intricacies of tax law. The public record did not then disclose his views on the great issues of freedom and liberty, immediately thereafter tested in the crucible of war and the almost equally troubled peace that followed. But through the years Chief Justice Traynor has repeatedly emphasized the important role of liberty in American society, the absence of need for conformity, and the freedom to be found in equality. "Only in the United States were men bound from the first to envisage together the status to be and to live for the most part as equals. In the process of growing rich and strong, we have laughed at liardship, we have laughed down pomp, we lave found our well-being and dignity in freedom."

But freedom is not license; the rights of liberty are accompanied by the rites of responsibility.

There is of course general agreement that no man's freedom is absolute. There is practical agreement on certain bases for restraint; thus the community values that make religious freedom virtually absolute nonetheless outlaw mutilation, witchcraft, and even polygamy. There is sporadic official censorship, despite widespread conviction of its inferiority to unofficial sanctions, in the name of community virtue easy to declare though impossible to define. There is substantial agreement that security is a legitimate basis for restraint im time of war. The real cleavage is on security in time of uneasy peace. Is there to be safety first at the expense of freedom? They cannot both be first. ${ }^{80}$

\section{A. Freedom of Speech}

The Traynor opimions in the free speech area show more growth and development probably than in any other portion of his constitutional philosophy. The early opinions, until about 1945 , emphasize the regulatory authority of the state as a basis for limitation of activities which

36 Traynor, No Magic Words Could Do It Justice, 49 CarIF. L. REv. 615, 625 (1961). 37 Ibid.

38 Traynor, Book Review, 46 CAIII. L. REv. 301 (1958).

80 Id. at 301-302. 
were by then beginning to receive recognition as protected by the first amendment.

The first case in which Justice Traynor was called upon to write in the free speech area, In re Bell, ${ }^{40}$ involved an attack by members of a labor union upon an anti-picketing ordinance. The union members were convicted of violating the ordinance and thereafter, in the case which reached the California Supreme Court, sought review by writ of habeas corpus. There was no substantial dispute that a portion of the ordinance was invalid on its face because of its inhibition of peaceful picketing contrary to the then recent case of Thornhill v. Alabama. ${ }^{41}$ Justice Traynor concluded that other portions prohibited picketing by acts of violence and were therefore vahi. Nonetheless, he would have reversed the conviction if the case had come up on direct appeal because the complaint, and thus the conviction, ambiguously charged petitioners with violation of any one "and/or" any other provision of the ordinance. However, he reasoned that the rule must be different in habeas corpus which "is in the nature of a collateral attack, and a judgment that is collaterally attacked carries with it a presuniption of regularity." ${ }^{242}$ Accordingly, the court held that petitioners had not met the burden of showing that their conviction was based on the unconstitutional portions of the ordinance. The holding now seems a more technical application of habeas corpus than has since been required by the Supreme Court of the United States; but, as we shall see, Chief Justice Traynor has continued to urge the distinction between issues that he beheves can be properly raised by habeas corpus as contrasted with those that are inappropriate for collateral attack, particularly contentions of unreasonable search and seizure. ${ }^{43}$

Three years later, in 1945, Justice Traynor again spoke for the majority of his court. The case, Payroll Guarantee Ass'n v. Board of Education, ${ }^{44}$ arose out of a petition for mandamus by petitioners who sought to use a San Francisco high school for an evening prograin in support of a proposed state constitutional amendment. In accordance with the provisions of a statute authorizing the use of school premises for certain civic purposes, the principal had certified that the proposed use would not conflict with school programs or other scheduled meetings. However, when the school board learned that the speaker's previous appearances had stimulated "noisy and boisterous" demonstrations, per-

4019 Cal. 2d 488, 122 P.2d 22 (1942).

41310 U.S. 88 (1940).

4219 Cal. $2 \mathrm{~d}$ at 500,122 P.2d at 29.

43 See Traynor, Mapp v. Ohio at Large in the Fifty States, 1962 Dure L.J. 319, 341.

4427 Cal. 2d 197, 163 P.2d 433 (1945). 
mission was withdrawn to avoid disturbance of classes scheduled to be held in other parts of the building on the same evening. Justice Traynor upheld the board's refusal to permit the meeting to be held, observing that "The primary task of the schools is education." Perhaps anticipating the United States Supreme Court ruling in Feiner v. New York, ${ }^{46}$ he said for the court:

If' a speaker in a school building or the opposition that he aroused attracted so much attention as to disturb school activities, it would not be for the police to curb those who incidentally caused the disturbances so long as the activities were lawful, but for the board i:. to prevent the occurrence of such a disturbance. Neither a speaker $\because$ " nor his opponents are thereby stilled; they may express themselves $\therefore$ fully and freely in school buildings as elsewhere whenever their $\therefore$ activities do not bring in their wake a disturbance of the regular school program: ${ }^{46}$

However technically sound may be the result in that case, and however consistent with the spirit of Feiner, it is hard to reconcile with more recent expressions of the Supreme Court of the United States. ${ }^{47}$

' "The decision in Payroll Guarantee Ass' $n$ has not been overruled by the California Supreme Court, nor is it necessary that it should be specifically discarded unless another "white horse"48 case comes along with identical facts. The principle for which the case might otherwise stand-that public officials may restrict speech likely to cause a disturbance-has not been accepted by the California Supreme Court. More to the present point, Roger Traynor has written the opinions which most effectively isolate the Payroll Guarantee Ass'n case, leaving it unsupported by more than its own rather special facts. In Ellis v. Board of Education, ${ }^{49}$ decided later in the same year, the same association which had been involved in the earlier case sought to use the same school building for the same speaker on a Sunday afternoon, when there would be no classes that might be subject to disturbance. This time they were met with the requirement they they furnish a large public liability insurance policy in the name of the school district. Now, however, the court, again through Justice Traynor, thought this condition an invalid limitation on speech; because the insured-against hazards "would arise from the

45340 U.S. 315 (1951).

$4627 \mathrm{Cal} .2 \mathrm{~d}$ at $203,163 \mathrm{P} .2 \mathrm{~d}$ at 436 . Compare the language of Chief Justice Vinson in Feiner: "Petitioner was thus neither arrested nor convicted for the making or the content of his speech. Rather, it was the reaction which it actually engendered." Feiner v. New York, 340 U.S. 315, 319-20 (1951).

47 See, e.g., Edwards v. South Carolina, 372 U.S. 229 (1963).

48 That is, a case indistinguishable on its facts, so referred to in the argument of Heart of Atlanta Motel, Inc v. United States, 379 U.S. 241 (1964). For a report of the argument, see 33 U.S.L. WEEK 3109 (Oct. 13, 1964).

4927 Cal. $2 \mathrm{~d} 322,164$ P.2d 1 (1945). 
failure of the district to maintain the premises and equipment in a reasonably safe condition or to fulfill its duties in managing the property. Although the decision was based specifically on the statute, ${ }^{51}$ the first amendment overtones were unmistakable.

The most important of the "school" cases decided in an opinion by Justice Traynor was Danskin v. San Diego Unified School District. ${ }^{62}$. As in Ellis, decided the previous year, the case was distinguishable on its facts from Payroll Guarantee Ass'n, and Justice Traynor made the point specifically, but the perspective from which the first amendment was viewed in the two cases appears to have been drastically different: In Danskin Justice Traynor made explicit the relevance of the first amendment, which had only been hinted at in the earlier cases. In Danskin a local affiliate of the American Civil Liberties Union had been denied use of a public school auditorium for a series of meetings on civil liberties in post-war America because its officers refused to sign a statutory oath disclaiming membership in "subversive" organizations. Payroll Guarantee Ass' $n$ was distinguished because the statutory provisions involved in Danskin "relate, not to the educational program of the schools, but to the protection of the community from 'subversive elements' . . Those who are under the ban of the statute could not hold a meeting to pronounce their views with regard to pending legislation, constitutional amendments, election of political candidates, or even artistic or educational matters. It is a drastic censorship ...." ${ }^{\prime 53}$ On this ground the state statute was invalidated, whereas in the earlier case nothing more than a local school board's discretionary denial of access was upheld. Now im. portant rehance was placed on the "clear and present danger" test as apphed by the United States Supreme Court in Bridges v. California. ${ }^{54}$ Noting that "the United States Supreme Court has been alive to the difference between negligible dangers and substantial ones, between remote dangers and immediate ones,",55 Traynor reahzed, prophetically as it turned out, that it could no longer be:assumed that Whitney v. Cali fornia, ${ }^{\text {"6 }}$ upholding the California Syndicalism Act, was still valid. Five years later Chief Justice Vinson was to make the same point for the United States Supreme Court:

Although no case subsequent to Whitney and Gitlow has expressly

50 Id. at 327,164 P.2d at 3.

51 "The purpose of the Legislature would be frustrated if petitioners" right to the free use of the school auditorium were nullified by the requirement that they furnish public liability insurance." Id. at 329,164 P.2d at 5 .

5228 Cal. 2d 536, 171 P.2d 885 (1946).

$58 \mathrm{Id}$. at $350-51,171 \mathrm{P} .2 \mathrm{~d}$ at 894 .

54314 U.S. 252,261 (1941).

6528 Cal. $2 \mathrm{~d}$ at 542,171 P.2d at 889.

58274 U.S. 357 (1927). 
overruled the majority opinion in those cases, there is little doubt that subsequent opinions have inclined toward the Holmes-Brandeis rationale. ${ }^{57}$

Justice Traynor was ahead of his time in Danskin, not only in this regard, but as well in the way he dealt with the question of loyalty oaths and disclaimer-of-membership requirements. Recognizing that "the state is under no duty to make school buildings available for public meetings, ${ }^{38}$ he nevertheless outhined compelling reasons why the school district could not deny use of its facilities to some groups on the specified terms while permitting their use to others.

[T] here is no escaping the conclusion that the Legislature denies access to a forum im a school building to "subversive elements," not because it believes that their public meetings would create a clear and present danger to the community, but because it believes the privilege of free assembly in a school building should be denied to those whose convictions and affiliations it does not tolerate. What it does not tolerate it seeks to censor. ${ }^{59}$

The opinion in Danskin should be regarded as the mature expression of Chief Justice Traynor's views on freedom of speech. The eloquent statement in that case, somewhat ahead even of the United States Supreme Court, has been vindicated by later decisions of the High Court, but never nore forcefully or directly. Even in Baggett $v$. Bullitt, ${ }^{60}$ expressly striking loyalty oaths and disclaimers required of public employees in the state of Washington, the emphasis was on "void for vagueness" rather than first amendment and fourteenth amendment grounds.

Chief Justice Traynor has remained true to the principles of the Danskin opinion even when dissent was necessary to sustain that principle. In 1957 the California Supreme Court, in five related cases, upheld the requirement of a loyalty oath as a condition of tax exemption sought by church groups and by a veteran of mihtary service. ${ }^{01}$ The majority thought the problem not difficult. Exemption from payment of taxes, they said, is a privilege which may be withheld on any reasonable ground, certainly including refusal to declare nonadvocacy of overthrow of the

57 Dennis v. United States, 341 U.S. 494, 507 (1951).

5828 Cal. $2 \mathrm{~d}$ at $545,171 \mathrm{P} .2 \mathrm{~d}$ at 891 .

59 Ibid.

60 377 U.S. 360 (1964). See also Cramp v. Board of Public Instruction, 368 U.S. 278 (1961); Wieman v. Updegraff, 344 U.S. 183 (1952).

61 Speiser v. Randall, 48 Cal. 2d 903, 311 P.2d 546 (1957); Prince v. City and County of Los Angeles, 48 Cal. 2d 472, 311 P.2d 544 (1957); First Methodist Churcl v. Horstmann, 48 Cal. 2d 901, 311 P.2d 542 (1957); People's Cluurcli of San Fernando Valley v. County of Los Angeles, 48 Cal. 2d 899, 311 P.2d 540 (1957); First Unitarian Church v. County of Los Angeles, 48 Cal. 2d 419, 311 P.2d 508 (1957). 
government by force or violence. Refusal of the tax exemption was not considered a denial of free exercise of religion (as to the church groups) or freedom of speech (as to the veteran) because advocacy was regarded as conduct not protected by the first and fourteenth amendments. Chief Justice Gibson and Justices Traynor and Carter dissented. Justice Traynor, for himself and Chief Justice Gibson, cited Danskin for the proposition that "a restraint on speech is not less a restraint when it is imposed indirectly through withholding a privilege rather than directly through taxation, fine, or imprisonment." 22 Relying explicitly on the first amendment, Traynor registered his dissent with memorable eloquence:

The issue thus narrows to whether a state can properly restrain free speech in the interest of promoting what appears to be eminently right thinking. A state with such power becomes a monitor of thought to determine what is and what is not right thinking ....

Errors in thought or expression are best counteracted by deeper thought and more cogent expression. Only through free discussion can subversive doctrines be understood and effectively combatted.83

The Supreme Court of the United States reversed all five cases, writing its principal opinion in Speiser v. Randall, ${ }^{64}$ and the first amendment was important to the result, but less directly so than in the Traynor dissent. "Where the transcendent value of speech is involved, due process certainly requires in the circumstances of this case that the State bear the burden of persuasion to slow that the appellants engaged in criminal speech." 105

That Chief Justice Traynor's enthusiasm for the first amendment was more than an affair of the moment has been conclusively demonstrated in later cases. In two notable instances Traynor's views of the free speech imperatives were not accepted by his own court or by the United States Supreme Court. Because it is highly unusual for Roger Traynor to be out of step with both courts, the two instances merit attention.

Black v. Cutter Laboratories ${ }^{66}$ is at best an unsatisfactory case for the development of constitutional principle because there has never been

62 First Unitarian Church v. County of Los Angeles, supra note 61, at 443,311 P.2d at 523 .

68 Id. at $448,450,311$ P.2d at 526,527 .

64357 U.S. 513 (1958). See also First Methodist Church v. Horstmann, 357 U.S. 568 (1958); First Unitarian Church v. County of Los Angeles, 357 U.S. 545 (1958) (Valley Unitarian-Universalist Church, Inc. v. County of Los Angeles); Prince v. City and County of San Francisco, 357 U.S. 513 (1958).

85 Speiser v. Randall, 357 U.S. 513, 526 (1958).

6843 Cal. 2d 788, 278 P.2d 905 (1955), cert. dismissed for want of substantial federal question, 351 U.S. 292 (1956). 
agreement as to the basic facts, specifically the reasons for which Cutter Laboratories discharged petitioner from her employment as a clerk typist. In seeking employment originally she had concealed that she was law trained and had worked for a law firm, and she had not disclosed earlier comrections with the Communist Party which might lead others to believe that she was also a member of the Party. However, the arbitrators to whom the question of the validity of the discharge was submitted ruled that the employer had waived these objections by not asserting them for two years after the facts were known. They concluded that the discharge was in fact a punishment for union activity and accordingly ordered reinstatement. A majority of the Cahifornia Supreme Court disagreed, finding "untenable" the arbitrators' holding that the discharge was for union activity. More important, the state court held that the award could not be enforced because "the very award itself is illegal in that it orders reinstatement as an employee of one whose dedication to and active support of Communist principles and practices stands proved and unchallenged in the record." of a Commumist was regarded as such a security threat that a contract by the employer with a union to keep a known Communist in its employ was against public policy and therefore illegal.

In response to this argument, Justice Traynor, dissenting, noted that the employer had waived whatever discharge riglits it could have asserted on the ground of Communist Party membership by failing to act for two and a half years. He continued: " $A$ fortiori such a contract by an employer with the employee is illegal. Thus by judicial fiat, but without the temerity to declare that Conimunists are deprived of civil rights .... the court abrogates not only the right of employers and unions to contract for the employment of Communists, but the riglit of Communists as a class to enter into binding contracts." Making perfectly plain the logical difficulties of this result Traynor raised these questions: "If it is illegal to employ a Communist, is it illegal to allow a Communist unemployment benefits? ${ }^{69}$ If the threat of commumist activity makes an employment contract with a known Communist illegal as against public policy, does it not also invalidate other contracts [with Communists]? .... If contracts with Communists are illegal, cannot Communists themselves violate them with impunity?"70

The United States Supreme Court originally granted certiorari, presuniably to provide some answers to these hard questions. ${ }^{71}$ But the

67 Id. at 800,278 P.2d at 912 .

$68 \mathrm{Id}$. at $811,278 \mathrm{P} .2 \mathrm{~d}$ at 919.

09 But cf. Flemming v. Nestor, 363 U.S. 603 (1960).

$7043 \mathrm{Cal} .2 \mathrm{~d}$ at $811-12,278$ P.2d at 919.

71350 U.S. 816 (1956). 
majority found either the facts or the law unmanageable. The Supreme Court avoided the necessity of answering the questions raised by Justice Traynor by not deciding the merits at all. Instead, the Court concluded that the decision below involved "only California's construction of a local contract under local law, and therefore no substantial federal question is presented."72 Chief Justice Warren and Justices Black and Douglas dissented in an opinion by Justice Douglas, providing a blunt answer to the questions asked by Justice Traynor.

I do not think we can hold consistently with our Bill of Rights that Communists can be proscribed from making a living on the assumption that wherever they work the incidence of sabotage rises or that the danger from Communist employees is too great for critical industry to bear. ${ }^{73}$

Whether this is the answer that Chief Justice Traynor would have given to the questions he raised as hypotheticals, he has had no occasion to disclose. But he did ask the questions.

Konigsberg $v$. State Bar of California ${ }^{74}$ was another case in which agreement was never reached as to the facts. The case went twice to the California Supreme Court and twice to the United States Supreme Court, and in each instance there was difficulty in determining the precise basis for the holding. ${ }^{75}$ The case began when the state committee of bar examiners refused to certify Konigsberg to practice law on the grounds that he had failed to prove (1) that he was of good moral character; and (2) that he did not advocate overthrow of the governnient by unconstitutional means. When the case first reached the Supreme Court in this posture Justice Black, for a five-member majority, noted that Komgsberg had refused to answer questions about his behefs and associations, relying on rights guaranteed by the first and fourteenth amendments, but observed that there was no showing that he had been denied admission on this ground. After a review of the evidence before the bar committee, including testimony that he was a former member of the Communist Party, the majority concluded that, even if true, "without anything more ... [it would not be] an adequate basis for concluding that he is disloyal or a person of bad character." "76 Accordingly, the judgment below was reversed and the case was remanded for further proceedings. Three Justices, however, dissented. Justice Frankfurter was

72351 U.S. 292, 299 (1962).

73 Id. at 304 .

74 52 Cal. 2d 769, 344 P.2d 777 (1959).

75 When the case was first presented to the California Supreme Court, the petition for review by the supreme court was denied by a four-to-three vote. Konigsberg v. State Bar of California, 353 U.S. 252, 254 (1957).

76353 U.S. at 273. 
not satisfied that the federal question had in fact been adjudicated in the state courts, so would have remanded to the Supreme Court of California for certification whether or not the fourteenth amendment due process claim had been properly presented to that court and decided there. ${ }^{77}$ Justices Harlan and Clark shared the jurisdictional doubts, but went further to express disagreement as well on the merits. They thought the issue to be decided was "whether it violates the Fourteenth Amendment for a state bar committee to decline to certify for admission to the bar an applicant who obstructs a proper investigation into his qualifications by deliberately, and without constitutional justification, refusing to answer questions relevant to his fitness under valid standards, and who is therefore deemed by the State, under its law, to have failed to carry his burden of proof to establish that he is qualified."

Upon remand the California Supreme Court vacated its prior order denying the petition for review and referred the entire matter once more to the committee of bar examiners. That committee conducted a further hearing at which Konigsberg was advised that his refusal to answer material questions would obstruct the investigation and prevent certification of his admissibility. Accordingly, when he refused to answer questions concerning membership in the Communist Party, certification was denied on the ground that he had refused to answer material questions. The California Suprente Court approved these findings and denied the application for admission to the bar, over the dissents of Justices Traynor and Peters. ${ }^{79}$ Justice Traynor agreed that an applicant could be denied admission to the bar for refusing to answer questions relevant to his qualifications to practice law, and that questions as to present or past membership in the Communist Party are relevant. Although the applicant would "ordinarily" have the burden of establishing qualification to practice law, to do so liere would pose "the immediate threat of prior restraint upon the free speech of all applicants. The possibility of inquiry into their speech, the heavy burden upon them to establish its innocence, and the evil repercussions of inquiry despite innocence, would constrain them to speak their minds so noncommittally that no one could ever mistake their innocuous words for advocacy." ${ }^{80} \mathrm{He}$ found a solution in a proposed shifting of the burden of proof as suggested earlier the same year by the Supreme Court of the United States in Speiser v. Ran-

77 Id. at 274-76.

$78 \mathrm{Id}$, at $279-80$.

79 Konigsberg v. State Bar of California, 52 Cal. 2d 769, 344 P.2d 777 (1959). Justices Traynor and Peters wrote separate dissents, but Justice Peters specifically adopted the reasons given by Justice Traynor.

80 $1 d$. at 776,344 P.2d at 782 . 
dall, discussed above. "This grave danger to freedom of speech could be averted without loss to legitimate investigation by shifting the burden to the examiners. Confronted with a prima facie case, an applicant would then be obliged to rebut it." ${ }^{\prime 82}$

In any event, Traynor did not believe it necessary to decide the constitutional question which would liave been posed if the state legislature liad directed that all applicants answer all questions relevant to the proscribed advocacy. The legislature had not so directed; the question was simply whether the court should impose such a requirement. Traynor thought there was no good reason for the court to do so, and he accordingly argued that Konigsberg should not be refused admission to the Bar simply for refusal to answer questions without the committee having first made out a prima facie case against him.

When the case returned to the United States Supreme Court a new majority was secured around the proposition, previously urged in dissent by Justice Harlan, that refusal to answer relevant questions was itself a sufficient ground for denial of admission. ${ }^{83}$ Now Harlan wrote the majority opinion, concluding that the California bar conmittee and the state court had not evaded the earlier decision of the United States Supreme Court (indeed, it had siniply followed the suggestion advanced in the earlier Harlan dissent as to an alternative ground for denying admission to the bar), and he ruled specifically on the new question:

We think it clear that the Fourteenth Amendment's protection against arbitrary state action does not forbid a State from denying admission to a bar applicant so long as he refuses to provide unprivileged answers to questions having a substantial relevance to his qualifications. ${ }^{84}$

Justice Black, writing for hinıself, Chief Justice Warren, and Justice Douglas, argued first that the second round of hearings in Cahifornia were inconsistent with the mandate of the United States Suprenre Court; second, and more urgently, he contended that to require answers to the questions asked of Konigsberg would in any event violate the first and fourteenth amendments.

Justice Brennan, in a brief dissenting opinion for hiniself and the Chief Justice, picked up intact the argunent nuade in Justice Traynor's

81 See discussion in text accompanying notes $61-65$, supra.

8252 Cal. $2 \mathrm{~d}$ at 776,344 P.2d at 782.

83 Komigsberg v. State Bar of California, 366 U.S. 36 (1961). Between the dates of the two decisions Justice Burton, who had voted with the unajority in Konigsberg $I$, retired and was replaced by Justice Stewart, who joined the previous dissenters to make a new unajority in Konizsberg II (as did Justice Whittaker, who did not participate in Konigsberg 1 ).

84 Id. at 44. 
dissent in the California Supreme Court. He argued for reversal "even if we assume with Mr. Justice Traynor" that a question as to present or past membership in the Commumist Party would be relevant; ${ }^{85}$ and he agreed with Traynor that if the burden of proof were shifted, as suggested in Speiser v. Randall-an opinion written by Justice Brennan-no basis had been laid for the bar examiners' questions.

With subsequent changes in the personnel of the Supreme Court of the United States, the majority ruling in Konigsberg II may be of doubtful authority. Even if there is not a disposition to go the whole distance of Justice Black's demal of authority to ask the questions, the intermediate position of Justice Traynor, building to the same result, might well be acceptable to 2 majority of the Court as now constituted.

\section{B. Freedom of Religion and Separation of Church and State}

Justice Traynor's first opmion involving the free exercise clause of the first amendment was in Gospel Army v. City of Los Angeles. ${ }^{80}$ In that case Gospel Army, an incorporated religious organization, brought suit to enjoin the enforcement against that organization of certain city ordinances regulating transactions in secondhand goods. The trial court found that plaintiff was "engaged exclusively in the promulgation, by literature and word of mouth, of its religious beliefs, by and through its auxiliaries, and in the procurement of donations in the form of money and articles of value in the prosecution and furtherance of its religious activities." ${ }^{\text {" }}$ Religious services at plaintiff's mission were conducted by a mimister who was paid out of solicited contributions. The ordinances required applications in writing, payment of fees, and official investigation of the "good character" of applicants before grant of the licenses, all desigued."to protect the public interest by preventing . . . . [junk dealers and secondhand] dealers from becoming outlets for stolen goods." - Justice Traynor sustained the ordinances, writing for a majority of four. The Traynor rationale was that the salvage activities of the charity, although "prompted by religious motives can hardly be differentiated from secular activities." 89 Accordingly, he concluded:

The requirement that promoters and the solicitors working under them submit proof of their good character and reputation does not discriminate against plaintiff or other religious organizations or censor their religious beliefs, nor does the regulation vest arbitrary power in the administrative board in authorizing it to withlold a license if it 
is not satisfied that the applicant is of good character and reputation. ${ }^{80}$

The dissenters were unwilling to separate, as did the majority, the charitable from the religious activities of the Gospel Army as a basis for allowing regulation of the former as secular functions. Justice Carter, for example, observed that

Both freedom of religious thouglit and freedom of religious action come within the protection of the bill of rights. This freedom cannot be whittled away by carving out segments of religious activities and relegating them to the realm of secular affairs. ${ }^{91}$

When this case and the closely related case, Rescue Army v. Municipal Court, ${ }^{92}$ were decided in 1945 and 1946 respectively by the California Supreme Court, recent decisions of the United States Supreme Court gave no clear guidance on this specific problem. Obviously, then, these were cases appropriate for Supreme Court review to permit further delineation of the meaning of the free exercise clause of the first amendment. Probable jurisdiction was noted in both cases, postpoming questions of jurisdiction to determination of the merits. After argument the Supreme Court dismissed both appeals, Gospel Army for want of jurisdiction on a finding that the California judgment was not final, ${ }^{03}$ and Rescue Army because the constitutional issues were not presented "in a clean-cut and concrete form, unclouded by any serious problem of construction relating either to the terms of the questioned legislation or to its interpretation by the state courts." 194

Justices Murplyy and Douglas dissented from the dismissal of the appeal in Rescue Army, urging that two constitutional issues were properly raised in that case: "(1) Does it violate the constitutional guarantee of freedom of religion to prohibit solicitors of religious charities from using boxes or receptacles in public places except by written permission of city officials? (2) Is that guarantee infringed by a requirement that such solicitors display an information card issued by city officials?"95

If those questions were before the United States Supreme Court today, it would not be difficult to speculate that both questions might be answered in the negative. ${ }^{96}$ Perhaps today Roger Traynor would not be

90 Id. at 248,163 P.2d at 714 .

01 Id. at 258,163 P.2d at 719 .

92 28 Cal. 2d 460, 171 P.2d 8 (1946). Chief Justice Gibson wrote the majority opinion in Rescue Army in which Justice Traynor concurred without opinion, while Justices Carter, Schauer, and Edmonds dissented as in Gospel Army.

93331 U.S. 543 (1947).

94331 U.S. 549, 584 (1947).

$95 \mathrm{Id}$. at 585 .

86 See, e.g., Sherbert v. Verner, 374 U.S. 398 (1963). 
dissatisfied with that result. ${ }^{97}$ But one can not be sure. One measure of Roger Traynor's greatness is that he is beholden to no man and to no immutable principle save the sacredness of free and full inquiry. Chief Justice Traynor's quest for constitutional truth has been illuminated by the lamps of freedom and equality. As those lanterns penetrate the gloom of constitutional doubts, new aspects of constitutional philosophy may yet take shape. The road ahead is ever better lighted, but the end is nowhere in sight.

97 See, e.g., People v. Woody, 61 A.C. 776, 40 Cal. Rptr. 69, 394 P.2d 813 (1964), in which Justice Tobriner, for a unanimous court, upset the conviction of Navaho Indians for use of peyote in a religious ceremony in violation of the Health and Safety Code. To apply the statute would "remove the theological heart of peyotism" despite the absence of any "compelling state interest." 